\title{
Global and Local Operations of Finnish Metal Industry Companies during COVID-19 and Trade Disruptions: A Case Study
}

\author{
Pasi Rönkkö \\ University of Oulu, Finland \\ pasi.ronkko@oulu.fi \\ Jere Lehtinen \\ University of Oulu, Finland \\ m2lehti@luukku.com \\ Jukka Majava \\ University of Oulu, Finland \\ jukka.majava@oulu.fi

\section{Pekka Tervonen \\ University of Oulu, Finland} \\ pekka.tervonen@oulu.fi
}

Purpose: Globally operating companies have been disrupted by many simultaneous crises in recent years, specifically the COVID-19 pandemic, Brexit, and trade wars. This study identifies the key factors in companies' decisions to expand their global supply chains or to operate more locally in today's world.

Study design/methodology/approach: This article contains a literature review and empirical study. Representatives from three Finnish B2B manufacturing companies in the metal industry were interviewed about their international and local operations.

Findings: The key reasons for global operations included a large supplier base, component availability, lower costs, and specialised products. Typical problems included quality issues, long lead times, and communication challenges. Specific risks and mitigations around COVID-19, Brexit, and trade wars are also presented.

Originality/value: The study provides updated global and local operations information. Unique reasons for global operations included manufacturing Engineerto-Order (ETO) products close to the customer and product changes.

Keywords: globalisation, supply chain, Industry, COVID-19, Brexit, trade wars, outsourcing, offshoring, reshoring

\section{Introduction}

Many companies have operations in various countries and even continents (Kraus et al., 2020). Probably the most well-known way to operate globally is by outsourcing non-core operations in countries with lower costs (Grossman \& Helpman, 2005; Mason \& Cole, 2002; Rondinelli \& Berry, 2000; Yang \& Chen, 2021), which is also called offshoring (Bailey \& De Propris, 2016). In this study, we refer to offshoring as "global operations", which include other aspects, such as global markets and suppliers. The reasons for global operations include lower material and labour costs, unique know-how to manufacture certain products, rare raw materials, and possible benefits of tax abatements (Manuj \& Mentzer, 2008). In addition, highly specialised companies with wide markets can produce larger batches to enable lower unit costs (Sayer, 1986). In extreme cases, companies may also benefit from the looser environmental policies of other countries (Christmann, 2004).

However, global supply chains are vulnerable to various risks despite the many economic advantages, including natural disasters, wars, strikes, and suppliers' bankruptcies (Chopra \& Sodhi, 2004; Kleindorfer \& Saad, 2005; Nandi et al., 2021; Tukamuhabwa et al., 2015). Moreover, disturbances in supply chain material, information, and cash flows can damage sales and increase costs (Chopra \& Sodhi, 2004). Global logistics is also a significant source 
of polluting emissions (Herold \& Lee, 2017; Ren et al., 2021) and harms the soil, groundwater, and environment in general (Rondinelli \& Berry, 2000).

Usually, companies are prepared for small risks, for example, through maintaining sufficient inventory and capacity levels in the entire supply chain and ensuring that redundant suppliers are dispersed geographically (Chopra \& Sodhi, 2004; Kraljic, 1983; Simchi-Levi et al., 2014). However, risk mitigation may be expensive even if disruptions do not occur (Chopra \& Sodhi, 2004). According to several authors (e.g., Chopra \& Sodhi, 2004; Simchi-Levi et al., 2014), high-impact, low-probability risks are usually overlooked. However, although disruptions in material flows can be damaging, they are pretty rare (Chopra \& Sodhi, 2004). As an exception, 2020-2021 included at least three simultaneous disruptions: the COVID-19 pandemic, Brexit, and the trade war between the United States and China. Especially the pandemic has shown how vulnerable global supply chains actually are; during this period, factories and borders have been closed around the world as a preventive action, disrupting logistics and manufacturing globally (Rio-Chanona et al., 2020; Zanoletti et al., 2021). In addition, Brexit has affected the competitiveness of European companies due to their dependency on the UK via value chains (Thissen et al., 2020), and the U.S.-China trade war has also had various effects on world trade (Boylan et al., 2021).

In terms of improving supply chain resilience (an ability to recover from disruptions for an even better performance state, see, e.g., Rönkkö et al., 2021), the lessons learned from the COVID-19 pandemic include supply chain localisation, agility, and digitalisation (Nandi et al., 2021). For over a decade, there has been a trend of reshoring production back to the origin countries (Bailey \& De Propris, 2016). The pandemic has accelerated this reshoring of manufacturing, which is enabled through robotics and automation (Studley, 2021).

In this article, we present the findings from a literature review and case company interviews, focusing on why companies choose to operate globally despite various risks and potential local alternatives. The reshoring trend is also examined. Although studies on supply chain disruptions during the COVID-19 pandemic already exist (Fonseca \& da Rocha, 2021; Mahajan \& Tomar, 2020; Rönkkö et al., 2021; Shaled et al., 2021), and the effects of Brexit have also been studied (Brady, 2021; Moradlou et al., 2021; Thissen et al., 2020), there is still a need for more country- and industry-specific studies. This study aims to clarify the reasons for global operations despite the risks and identify the barriers to more local operations. In order to meet these objectives, the following research questions have been formulated:

RQ 1 What are the key reasons for the case companies to operate globally?

RQ 2 What are the barriers to local alternatives in the case companies?

This study addresses the research questions qualitatively through a literature review and an analysis of industry interviews. Three B2B manufacturing companies in the metal industry were interviewed to obtain empirical evidence. The article is structured as follows. Chapter 2 presents a literature review focusing on supply chain management, specifically global and local operations, outsourcing, offshoring, and reshoring. Chapter 3 describes the research method and data collection. Chapter 4 shows the interview results, chapter 5 discusses the empirical findings compared to the literature, and chapter 6 presents the conclusions.

\section{Literature Review}

\subsection{Outsourcing}

Shortened product life cycles, increased competition, customer demand for high-quality, lowcost products, short lead times, and varying lot sizes have led companies to focus on their core 
operations (Grossman \& Helpman, 2005; Mason \& Cole, 2002; Rondinelli \& Berry, 2000; Yang \& Chen, 2021). Non-core operations are the first candidates for outsourcing, whereas operations that enable serving customers better or deal directly with core products or services should be kept in-house. Outsourcing non-core activities may lead to competitive advantage if they can be completed faster, cheaper, or better (Lankford \& Parsa, 1999).

Some commonly outsourced functions are product design, marketing, assembly, manufacturing, research and development, distribution, and after-sales services. However, it is not unusual for most of a company's operations to be outsourced (Mason \& Cole, 2002). In the extreme case, a company does not do its own production but is only a virtual company. For example, it is common for companies in the developed countries to only design a product and outsource the manufacturing to other countries to save labour costs, improve worker productivity, and free up capital by cutting fixed costs (Bailey \& De Propris, 2016; Chen \& Liu, 2021; Grossman \& Helpman, 2005; Mason \& Cole, 2004). According to Mason and Cole (2004), investments in a company's own manufacturing assets may become a burden if the technology changes or the demand collapses. Therefore, companies may buy some technologies that would be too expensive to replicate internally (Grossman \& Helpman, 2005). Outsourcing is also a way for companies to benefit from diversified operation advantages and global markets (Yazdani et al., 2021).

One of the most well-known benefits of outsourcing is reduced costs because companies utilise their existing assets and reduce the need for their own investments (Jung, 2020; Lankford \& Parsa, 1999; Mason \& Chen, 2002; Yang \& Chen, 2021). This simultaneously benefits the contract manufacturers, who may invest in more advanced technology because of greater demand for production (Chen \& Liu, 2021). Outsourcing also increases production agility, which is necessary to reduce inventories, smoothen the production levels, adapt to customer demands and market variations, and integrate with suppliers more effectively (Mason \& Cole, 2002). In addition, Lankford and Parsa (1999) mention expanded services and expertise, improved employee productivity, and a more positive corporate image. If the quality of the components manufactured by a contract manufacturer is better than that of the original equipment manufacturer (OEM), it can improve the value and quality of the final products and decrease the need for reworking and maintenance costs (Yang \& Chen, 2021).

While outsourcing has definite advantages, Lankford and Parsa (1999) mention that determining the core competencies needed in certain operations can sometimes be tricky, and wrongly determining these can be lethal for the company. For example, incorrect choices in outsourcing partners can lead to performance or quality issues (Yazdani et al., 2021). When companies outsource, the quality is not in their hands (Yang \& Chen, 2021). Even contracts cannot ensure that the production is done with the same care as in the outsourcing company (Grossman \& Helpman, 2005). Poor-quality products can lead to delivery delays and penalties for the outsourcing company, and sub-par components can also affect the safety and reliability of the final products (Yang \& Chen, 2021). Global outsourcing especially increases the OEM's uncertainty in its supply chain concerning yield, capacity, lead time, and disruption risk (Chen \& Liu, 2021; Yazdani et al., 2021). Moreover, Sayed et al. (2021) argue that sustainability practices can be difficult to implement if the responsibility rests in the hands of a contractor rather than in-house. Thus, outsourcing can be risky if the risks are not considered and evaluated (Yazdani et al., 2021). Outsourcing also can increase logistics and warehousing costs, including insurance, tariffs, and customs, and present risks related to supply disruptions, employee motivation, and foreign exchange (Yazdani et al., 2021).

Successful outsourcing and offshoring require finding a partner that can fulfil the company's needs. Sometimes, the technology needed to manufacture specialised components determines 
the willingness of a potential partner to invest in new equipment (Grossman \& Helpman, 2005). Outsourcing is likely to be more successful if communication and transportation infrastructures are at a sufficient level. Contract manufacturers near the OEM can streamline the supply chain and reduce lead time and transportation costs (Mason \& Cole, 2002). However, the performance of third-party providers should be inspected carefully because poor quality can lead to loss of customers, market share, and reputation (Dey et al., 2021; Mason \& Cole, 2002; Yang \& Chen, 2021).

\subsection{Global Operations and Offshoring}

One common form of outsourcing is offshoring, which means that some parts of the supply chain, or the entire production, are shifted to another country. The terms outsourcing and offshoring are used almost interchangeably. However, the difference is that the production is shifted outside the country in offshoring. In contrast, in outsourcing, the non-core operations are allocated to other stakeholders located in the same or a different country (Bailey \& De Propris, 2016). The reasons for offshoring include lower material and labour costs (Grossman \& Helpman, 2005; Jung, 2020; Manuj \& Mentzer, 2008), rare materials not available domestically, unique abilities to manufacture certain products, and tax abatements (Manuj \& Mentzer, 2008). A company's high specialisation is another reason; if the markets are worldwide, large production batches are enabled, thus lowering the set-up costs (Sayer, 1986). Accordingly, worldwide supply operations enable more security because the supplier pool may be larger. Thus, offshoring can be used strategically to extend the supplier base (Jung, 2020). In addition, lower material and labour costs may significantly benefit the final customers by lowering prices (Jung, 2020). However, in extreme cases, to keep these costs down, globally operating companies may perform dirty operations in countries where the environmental regulations are less strict (Christmann, 2004). Another major reason for offshoring and economic globalisation is that firms need to produce and deliver goods faster to their customers worldwide (Rondinelli \& Berry, 2000). Globalised and interconnected manufacturing are possible if the trade barriers, transportation costs, and tariffs are low enough because the costs increase when borders are crossed. Marketing and design might also be done in countries near the potential customers (Grossman \& Helpman, 2005).

Even though globally operating companies can exploit looser environmental policies, ensuring sustainability in operations can also be a competitive factor. Customers have the power to affect a company's assuming this responsibility through their purchasing decisions. Thus, even one subsidiary can affect the company image if it acts irresponsibly (Christmann, 2004). Rondinelli and Berry (2000) describe how negative environmental impacts can harm a company's reputation. Görg and Strobl (2000) mention that globally operating companies can disturb the production and development of certain industries in some countries by competing against domestic manufacturers with larger product offerings and lower prices. However, international companies can also significantly increase the product demand of local intermediary manufacturers. The most common reasons for outsourcing, global operations, and offshoring, according to the literature, are presented in Table 1.

Table 1: Reasons for Outsourcing, Global Operations, and Offshoring

\begin{tabular}{|l|l|}
\hline Reason & Author(s) \\
\hline Lower material and labour costs & $\begin{array}{l}\text { Grossman \& Helpman, 2005; Jung, 2020; Manuj \& } \\
\text { Mentzer, 2008 }\end{array}$ \\
\hline Outsourcing non-core and non-value-adding activities & $\begin{array}{l}\text { Grossman \& Helpman, 2005; Mason \& Cole, 2002; } \\
\text { Rondinelli \& Berry, 2000; Yang \& Chen, 2021 }\end{array}$ \\
\hline Wider markets and supplier base & $\begin{array}{l}\text { Grossman \& Helpman, 2005; Jung, 2020; Sayer, } \\
1986 ; \text { Yazdani et al., 2021 }\end{array}$ \\
\hline Reduced need for own investments & Bailey \& De Propris, 2016; Chen \& Liu, 2021; \\
\hline
\end{tabular}




\begin{tabular}{|l|l|}
\hline & Grossman \& Helpman, 2005; Mason \& Cole, 2004 \\
\hline Rare materials & Manuj \& Mentzer, 2008 \\
\hline $\begin{array}{l}\text { Specialised products, economies of scale, and large } \\
\text { production batches }\end{array}$ & Sayer, 1986 \\
\hline Know-how and competence & Manuj \& Mentzer, 2008 \\
\hline Less strict environmental policies & Christmann, 2004 \\
\hline Faster entry to the markets (speed-to-market) & Rondinelli \& Berry, 2000 \\
\hline Tax abatements & Manuj \& Mentzer, 2008 \\
\hline Agility & Mason \& Cole, 2002 \\
\hline
\end{tabular}

\subsection{Local Operations and Reshoring}

During the last decade, there has been a trend to bring production facilities back from offshoring countries to the countries where they were originally located (Bailey \& De Propris, 2016). In the literature, this is referred to as backshoring, onshoring, or reshoring (Jung, 2020). The most common reason for reshoring is shrinking cost-benefit (Jung, 2020; Kazmer, 2014). Even though salaries may be lower in developing countries, other costs, such as logistics costs, production costs, and tariffs, may have increased (Jung, 2020; Yang et al., 2021). Yang et al. (2021) claim that tariffs can be a significant reason for reshoring. According to Studley (2021), COVID-19 has accelerated the onshoring of manufacturing, which is enabled through robotics and automation. Automation and high-skilled employees can easily replace low-skilled employees and their manual tasks.

In addition, onshore manufacturing can be a national strategy to combat slowing economic growth. The reasons for reshoring might also include strategic concerns, such as intellectual property rights (IPR), domestic goodwill, risk management, and taxes (Kazmer, 2014). Other motivations are low quality, inflexibility, high labour costs, and transportation costs (Bailey \& De Propris, 2016). Domestic production might also be protected by tariffs (Yang et al., 2021). According to Bailey and De Propris (2016), one significant reason for reshoring is supply chain resilience. Onshore suppliers enable a faster market response and shorter lead time, and a critical trade-off for companies is to choose between costs and responsiveness (Jung, 2020). Especially if the goods have short obsolescence cycles, long lead times can expose companies to significant risk (Chopra \& Sodhi, 2004).

\section{Research Process}

The research was conducted as a case study. According to Yin (2003), this is a suitable method of studying contemporary phenomena free from researcher bias. The research process involves designing the study, conducting a literature review and company interviews, analysing the data, documenting the findings, and forming conclusions (Figure 1).

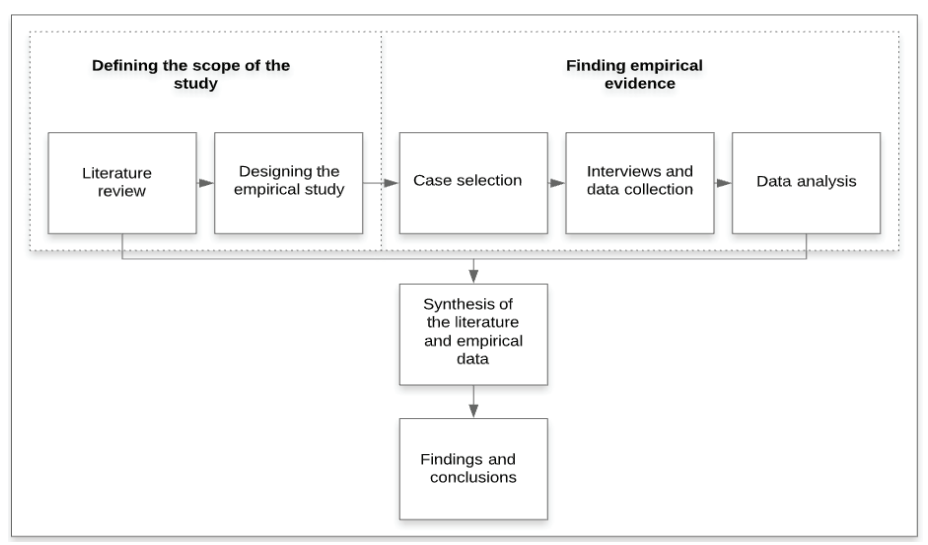

Figure 1: The Research Process of the Study 
The descriptive literature review is based on peer-reviewed journal articles published between 1983 and 2021. The oldest articles included are cornerstone publications in the fields of supply and global operations. The base articles were found in the Scopus database using various search terms, for instance, "global" and "operations"; "global" and "supply chains"; "global" and "supply chain" and "challenge"; "local" and "supply chain"; "outsourcing"; "offshoring"; and "onshoring" or "backshoring" or "reshoring". In addition, some related articles were found in the articles that were read, using the "snowball sampling method".

The interviews took place in three Finnish B2B manufacturing companies in the metal industry and were performed between January and March of 2021. The companies were chosen according to their operations and the criterion of their having both local and global operations. The empirical research data was collected using a semi-structured questionnaire with the following questions: (1) which operations are global and local in your company; (2) what types of challenges exist in both your global and local operations; (3) how are the global operations developed in your company; (4) what factors have promoted the globalisation of your company and its operations; (5) what global crises have your company faced and how have they affected its operations; (6) what products have global supply chains; (7) what the difference in the cost structure between the global and local supply chains is; and (8) how are the issues related to suppliers' quality, costs, environment, safety, and health considered. The information on the companies and the interviewees' roles are presented in Table 2.

Table 2: Interviewed Companies

\begin{tabular}{|l|l|l|l|l|}
\hline Company & Revenue & Personnel & Products & Roles of the interviewed persons \\
\hline $\mathrm{C} 1$ & $>100 \mathrm{M} €$ & 450 & $\begin{array}{l}\text { Automation } \\
\text { technology solutions }\end{array}$ & CIO \\
\hline $\mathrm{C} 2$ & $<50 \mathrm{M} €$ & $<300$ & Metal & CEO \\
\hline $\mathrm{C} 3$ & $>150 \mathrm{M} €$ & $<500$ & Windmill gears & Purchasing director \\
\hline
\end{tabular}

All the interviewed companies operate in the metal industry but are specialised in different products, such as automation solutions for machining (C1), metal (C2), and windmill gears (C3). For example, C1's products include an automatic warehouse solution that supplies machining equipment with materials and finished materials and another for tooling the machining systems automatically. C1 also does mechanical and electrical design, manufacturing, and software planning and development for the delivered products. C2, a subsidiary company delivering components products to customers, has a more traditional supply chain.

\section{Results}

\subsection{Global Operations, Offshoring, and Reshoring}

All the case companies operate globally and locally, in various forms and for various reasons. The production is mainly done in Finland, where the goods are delivered worldwide. C2 has subsidiaries in Estonia, Sweden, and Russia and a sales company in Switzerland. C3 has subsidiaries in other countries as well. Its head office is in Finland, but it has service and sales units in other European countries. C1 offers an aftermarket service consisting of a spare parts business, modernisation of systems, and repair and installations, which are provided 24/7 around the globe. Some support functions, such as HR, economics, and ICT, are also organised globally. The local operations of C3 are based mainly on sales and markets.

The case companies purchase components both globally and locally. C2 purchases mainly from the EU, while $\mathrm{C} 3$ mentioned that "usually, the supply chains are abroad, but some materials and components, such as gaskets, bearings, cast iron, machinery, covers, and 
flanges are purchased locally from Finland". Some of C1's suppliers are global, but the company uses domestic suppliers for shelving solutions and some raw materials (e.g., steel).

\subsection{Reasons for Global Operations}

$\mathrm{C} 1$ has two main reasons for operating globally: some goods are delivered from abroad, and the company has customers globally. Roughly $90 \%$ of the company's revenue comes from international customers, mainly in Europe, the United States, and Asia. Exports account for roughly $40 \%$ of C2's revenue; its main markets are in the EU, but some product families are exported to Asia and the US. The study companies are globalised because domestic markets are too small for highly specialised industries. However, a specialised industry may also be a reason for sourcing the components abroad (C1). Growth has been achieved through globalising the operations, and acquisitions have enabled growth in European markets (C1). There is an apparent reason for specialised production; for example, with $\mathrm{C} 2$, a small number of customers create most sales, and thus the company must provide specialised products.

The major reason companies launch global operations is the market $(\mathrm{C} 2, \mathrm{C} 3) . \mathrm{C} 2$ stated that "if the markets are somewhere else and you operate locally, there will be some challenges in deliveries" and "if the core competence and markets are separate, it is harder to compete". Thus, if some key markets are abroad, the company benefits from being near these customers. For example, "There are no wind turbine manufacturers in Finland, and thus there are no customers" (C3). C2 seeks growth and aims to globalise to obtain more significant market shares. It recognises that "if the company wants to grow, it has to be globalised and specialised". One way to acquire a more significant market share is to fulfil the needs of large customers. The current growth in $\mathrm{C} 2$ has been achieved in the pull of the large customers and by investing in the customers. Many of C2's customers have moved their decision-making out of Finland, and in many companies, the ownership has become international. There have also been changes in organisational structures.

Cost savings is also a common reason for global operations. For example, in C1, "global supply chains may offer many opportunities, such as savings in costs". Vice versa, if the company only operated locally and used domestic suppliers, the costs would rise significantly. For C3, the costs in China are clearly lower, and some customers demand local deliveries in China. C3's customers also require the assembling of products in China. Overall, "global operations may lead to challenges, but to get the benefits, they should be accepted".

Besides lower costs, all the needed components are not manufactured or available domestically, or the capacity of the domestic suppliers may be lower, which has led to global purchasing operations (C3). If the components were available domestically, the price would usually be higher, but not always (C3). Today, Chinese suppliers compete equally with European manufacturers, but Chinese components take longer to arrive because they are delivered by sea freight, with delivery times up to several weeks. Airfreight and train are other options for components delivery, but they are more expensive (C3).

Changes in products were also found to lead to global operations. For example, the sizes of wind turbines have grown significantly. Simultaneously, this has increased the sizes of the products and components manufactured by $\mathrm{C} 3$, doubling their weight. The domestic suppliers simply do not have components of this size available. In $\mathrm{C} 3$, "the customers have grown, leading to a situation where the customers' words have bigger value than before". This means that the customers may determine where the manufacturer purchases the components $(\mathrm{C} 3) . \mathrm{C} 1$ has also faced industry changes because, in the automotive industry, the demand for combustion engines has decreased. The companies are fighting for their existence and thus are 
not investing in new machines, which has affected C1's business: "The customers are not taking as many risks as before".

\subsection{Risks, Challenges, and Risk Mitigation of Global Operations}

The case companies have various common but also industry-specific challenges. For example, $\mathrm{C} 1$ 's challenges are related to quality assurance, delivery times, and demand prediction. Especially for $\mathrm{C} 1$, demand prediction is challenging because the deliveries are Engineer-toOrder projects, which have a delivery time of 10-12 months: "When the deal has been made, the acts should be immediate, and purchase orders should be made for components." For example, purchasing steel and delivering it to the manufacturing plant takes many months. $\mathrm{C} 2$ also faces challenges related to the forecasts: "Currently, the forecasts do not enter the system automatically, but transparency is sought in supply chains". To improve visibility in its supply chain, $\mathrm{C} 1$ has an automatised system to deliver purchasing orders to its suppliers and aims to improve information visibility in its supply chain. For example, sales forecasts are shared, and demand is predicted, especially for warehouse management (C1).

Ethical and quality issues, such as preventing child labour and promoting sustainable development, are considered already in the purchasing contracts $(\mathrm{C} 1, \mathrm{C} 2, \mathrm{C} 3)$. In addition, internal and external audits are performed periodically concerning the suppliers, and customers also audit the case companies $(\mathrm{C} 1, \mathrm{C} 2, \mathrm{C} 3) . \mathrm{C} 2$ mentions that the "importance of sustainable development has been emphasised for suppliers. It may be a significant issue when choosing new suppliers, because it may have a huge meaning in health and safety". Compliance with the Occupational Safety and Health Act is a part of the strategic message, and it is also required. The companies have valid certificates, such as the ISO 9001 quality system, ISO 14001 environmental management system, and IATF 16949 quality management system for the automotive industry (C2). For C3, choosing suppliers brings its own challenges, for example, those from China.

Distance has inherent challenges in global supply chains. However, this risk can be mitigated by maintaining extensive inventories (C2). Freight costs are also naturally higher (C2), and the obsolescence of products is a concern because quality risks increase as the length of the time in transportation increases (C2). For example, metal products do not usually suffer in delivery. However, they may be hard to handle because of their sizes; besides, they may be prone to temperature variations and seawater damage $(\mathrm{C} 2)$.

The COVID-19 pandemic has been a challenge for all the companies. For example, C2 preferred local supply chains to secure components delivery because the pandemic affected the supply chains. C3's production was affected heavily, especially its operations in Italy and China, which were considerably hampered at the pandemic's beginning. However, the pandemic also has provided a valuable motivation to implement remote operations (C2).

Furthermore, Brexit has presented unique challenges, such as increased formalities in borders, which have lengthened delivery times (C1). Brexit did not significantly affect $\mathrm{C} 3$, although it caused delays and increased costs at its sales company in the UK. Another issue affecting the companies is trade wars (C1, C3). Global trade wars, especially between the United States and China, led to higher costs and market challenges in Asia, Europe, and the United States. They also caused a lack of willingness in customers to invest (C1). C3 has also had challenges in its container deliveries due to trade wars.

\subsection{Reasons for Local Operations}

All the companies experience benefits from local operations, such as close markets (C2), secured and safe supply chains (C2), the same cultural environment (C2), good quality and 
easier quality control $(\mathrm{C} 2, \mathrm{C} 3)$, shorter delivery times, and faster lead times $(\mathrm{C} 2)$. In $\mathrm{C} 2$, the quality challenges are easier to solve in local operations due to faster and easier communication. In $\mathrm{C} 3$, it is usually easier to work and communicate with local suppliers. Communication is crucial when manufacturing ETO products since they are produced in cooperation with product designers and customers (C2). A secured supply chain is important for many reasons. For $\mathrm{C} 2$, one reason is that "demand and needs of low-volume, high-mix products are sometimes surprising, and in that case, local suppliers are better". In some cases, the overall costs do not determine which products are purchased locally because availability is the most important issue.

Centralisation in a single location can also be very important. In $\mathrm{C} 1$, the achieved benefits include lower costs, better logistics and delivery control, and better quality control. C2 has competence centres located in their factories. Operations, such as planning and other technical competence tasks, are performed in these centres because scaling these operations elsewhere might be difficult. Capital, operations, and competence are all factors to consider when deciding to relocate $(\mathrm{C} 2)$.

\section{Discussion}

The study findings support the existing literature regarding the typical challenges, benefits, and opportunities related to global operations. However, some new issues were identified, such as the COVID-19 pandemic, Brexit, the trade wars, and container shortage, which have disturbed global operations. The general findings of this study are synthesised in Table 3 and compared with the literature review findings.

Table 3: Synthesis of the Case Study and Literature Findings

\begin{tabular}{|c|c|c|c|}
\hline \multicolumn{4}{|c|}{ Global operations } \\
\hline Finding & Case study & Literature & Author(s) \\
\hline $\begin{array}{l}\text { The components are purchased globally if local } \\
\text { substitutes are not available, or there is not } \\
\text { sufficient domestic capacity }\end{array}$ & $\mathrm{x}$ & $\mathrm{x}$ & Manuj \& Mentzer, 2008 \\
\hline $\begin{array}{l}\text { Lower costs, high specialisation, and wider markets } \\
\text { and supplier base }\end{array}$ & $\mathrm{x}$ & $\mathrm{x}$ & Manuj \& Mentzer, 2008 \\
\hline $\begin{array}{l}\text { The specialisation requires wider markets and thus } \\
\text { customers globally }\end{array}$ & $\mathrm{x}$ & $\mathrm{x}$ & $\begin{array}{l}\text { Grossman \& Helpman, } \\
\text { 2005; Jung, 2020; Sayer, } \\
\text { 1986; Yazdani et al., } 2021\end{array}$ \\
\hline $\begin{array}{l}\text { Global purchasing does not necessarily save costs } \\
\text { due to rising logistics costs, tolls, and tariffs. }\end{array}$ & $\mathrm{x}$ & $\mathrm{x}$ & $\begin{array}{l}\text { Jung, 2020; Kazmer, 2014; } \\
\text { Yang et al., } 2021\end{array}$ \\
\hline $\begin{array}{l}\text { Engineer-to-Order (ETO) products require } \\
\text { communication between different stakeholders, and } \\
\text { thus they have to be made close to the customer }\end{array}$ & $\mathrm{x}$ & & \\
\hline $\begin{array}{l}\text { Quality issues, longer lead time, and more } \\
\text { challenging communication are typical problems }\end{array}$ & $\mathrm{x}$ & $\mathrm{x}$ & Yazdani et al., 2021 \\
\hline Changes in products led to global operations & $\mathrm{x}$ & & \\
\hline $\begin{array}{l}\text { Large inventories and wider supplier pools are used } \\
\text { to mitigate the risks of global operations }\end{array}$ & $\mathrm{x}$ & $\mathrm{x}$ & $\begin{array}{l}\text { Chopra \& Sodhi, 2004; } \\
\text { Kraljic, 1983; Simchi-Levi } \\
\text { et al., } 2014\end{array}$ \\
\hline \multicolumn{4}{|c|}{ Local operations } \\
\hline Finding & Case study & Literature & \\
\hline Local operations enable flexibility & $\mathrm{x}$ & $\mathrm{x}$ & Bailey \& De Propris, 2016 \\
\hline $\begin{array}{l}\text { Increasing local operations and reshoring to } \\
\text { increase the security of supply }\end{array}$ & $\mathrm{x}$ & $\mathrm{x}$ & $\begin{array}{l}\text { Nandi et al., 2021; Studley, } \\
2021\end{array}$ \\
\hline
\end{tabular}




\begin{tabular}{|l|l|l|l|}
\hline $\begin{array}{l}\text { Planning and other competence-intensive tasks are } \\
\text { difficult to scale elsewhere }\end{array}$ & $\mathrm{x}$ & $\mathrm{x}$ & $\begin{array}{l}\text { Grossman \& Helpman, } \\
\text { 2005; Mason \& Cole, 2002; } \\
\text { Rondinelli \& Berry, 2000; } \\
\text { Yang \& Chen, 2021 }\end{array}$ \\
\hline $\begin{array}{l}\text { Close markets, secured and safe supply chains, } \\
\text { similar cultural environment, good quality and } \\
\text { easier quality control, shorter delivery times, and } \\
\text { faster lead times }\end{array}$ & & $\mathrm{x}$ & $\begin{array}{l}\text { Bailey \& De Propris, 2016; } \\
\text { Yazdani et al., 2021 }\end{array}$ \\
\hline
\end{tabular}

The COVID-19 pandemic has significantly affected global supply chains because of closed factories and borders, thus generating huge risks (Rio-Chanona et al., 2020; Zanoletti et al., 2021). One case company was prepared to lower production because of its operations in Italy and China at the beginning of the pandemic. Another preferred to use more local supply chains to secure supply, which is in line with Nandi et al. (2021) and Studley (2021) regarding the pandemic's acceleration of manufacturing offshoring. Larger inventories were also a way to mitigate risks related to complex supply chains, which supports the earlier findings of Chopra and Sodhi (2004) and Tukamuhabwa et al. (2015).

The typical reasons for global operations, both in the literature and empirical results, were lower costs, wider markets, and high specialisation. The case companies are highly specialised; for example, $\mathrm{C} 3$ specialises in wind turbine gears and $\mathrm{C} 1$ in automation solutions of machining equipment. As a result, wide and global markets are needed (Sayer, 1986). Some novel reasons for initiating global operations were also found. For instance, changes in products led C3 to develop its global supply chain due to the unavailability of domestic production. Engineer-to-Order types of products also favoured global operations. The typical risks of global operations include quality issues, more challenging communication, and longer lead times. Long transportation routes add costs and may decrease product quality. For example, sea transportation may affect goods exposed to seawater or temperature variations.

\section{Conclusions}

This study aimed to identify the major reasons companies operate globally despite significant risks, such as those related to the COVID-19 pandemic, Brexit, and trade wars. For empirical evidence, three companies in the metal industry were studied. This study has both academic and managerial implications: first, it gives insight into how different companies operate globally during large changes in the market, and secondly, it offers fresh views regarding the risks to companies involved in global operations.

Three main reasons were found for operating globally. First, when companies manufacture highly specialised products, global markets enable sufficient production volumes. Second, some specialised goods are only manufactured in certain locations. Third, to be competitive, the prices of the purchased components should be low enough to manufacture final products that are not too expensive. Usually, this is possible only when the components are purchased from countries with lower labour and material costs. However, some indications indicate that the price gap of the components purchased globally has shrunk because of higher logistics costs and tariffs. Finally, local purchasing alternatives enable flexibility and faster delivery. Although there are major risks in global operations, sometimes they are the only option to compete in the market, and thus they are pursued. However, the significance of some global operations, such as global purchasing, has decreased. There has been a growing trend towards reshoring offshored operations to mitigate the risks and harms; indeed, some evidence has shown that COVID-19 has boosted reshoring and local operations. 
As a case study, this study has some natural limitations. For example, only three companies were studied, and only one person was interviewed from each company, which makes generalisations difficult. In future research, the study could be repeated with other types of companies and with participants from different levels and with different tasks in the organisation. This study also could be executed in different countries to obtain unique, country-specific data.

\section{Acknowledgements}

The authors would like to thank all the participants contributing to this research.

\section{References}

Bailey, D., \& De Propris, L. (2016). Manufacturing reshoring: A UK perspective. In R. Hira \& J. Eatie (Eds.). Engineering globalisation reshoring \& nearshoring: Management \& Policy Issues, Singapore: World Scientific.

Boylan, B. M., McBeath, J., \& Wang, B. (2021). US-China relations: Nationalism, the trade war, and COVID19. Fudan Journal of the Humanities and Social Sciences, 14, 23-40.

Brady, M. (2021). Realising supply chain resilience - An exploratory study of Irish firms' priorities in the wake of Brexit. Continuity \& Resilience Review, 3(1), 22-36.

Chen, Z., \& Liu, F. (2021). Multi-outsourcing supply chain coordination under yield and demand uncertainties. Experts Systems with Applications, 181, 115177.

Chopra, S., \& Sodhi, M. S. (2004). Managing risk to avoid supply-chain breakdown. Massachusetts Institute of Technology Sloan Management Review, 46(1), 53-61.

Christmann, P. (2004). Multinational companies and the natural environment - Determinants of global environmental policy standardisation. Academy of Management Journal, 47(5), 747-760.

Dey, B. K., Bhuniya, S., \& Sarkar, B. (2021). Involvement of controllable lead time and variable demand for a smart manufacturing system under a supply chain management. Experts Systems with Applications, 184 115464.

Fonseca, L., \& da Rocha, A. (2021). Rethinking offshoring and international marketing strategies during the COVID-19 pandemic. Journal of Contemporary Administration, 25. DOI: doi.org/10.1590/19827849rac2021200216.en

Görg, H., \& Strobl, E. (2002). Multinational companies and indigenous development - An empirical analysis. European Economic Review, 46(7), 1305-1322.

Grossman, G. M., \& Helpman, E. (2005). Outsourcing in a global economy. Review of Economic Studies, 72, $135-159$.

Herold, D. M., \& Lee, K. H. (2017). The influence of the sustainability logic on carbon disclosure in the global logistics industry: The case of DHL, FDX and UPS. Sustainability, 9(4), 601.

Jung, S. H. (2020). Offshore versus onshore sourcing: Quick response, random yield, and competition. Production \& Operations Management, 29(3), 750-766.

Kazmer, D. O. (2014). Manufacturing outsourcing, onshoring, and global equilibrium. Business Horizons, 57, 463-472.

Kleindorfer, P. R., \& Saad, G. H. (2005). Managing disruption risks in supply chains. Production and Operations Management, 14(1), 59-68.

Kraljic, P. (1983). Purchasing must become supply management. Harvard Business Review, September-October 109-117.

Kraus, S., Clauss, T., Breier, M., Gast, J., Zardini, A., \& Tiberius, V. (2020). The economics of COVID-19: Initial empirical evidence on how family firms in five European countries cope with the corona crisis. International Journal of Entrepreneurial Behaviour Research, 26(5), 1067-1092.

Lankford, W. M., \& Parsa, F. (1999). Outsourcing: A primer. Management decision, 37(4), 310-316.

Mahajan, K., \& Tomar, S. (2020). COVID-19 and supply chain disruption - Evidence from food markets in India. American Journal of Agricultural Economics, 103(1), 35-52.

Manuj, I., \& Mentzer, J. T. (2008). Global supply chain risk management. Journal of Business Logistics, 29(1), $133-155$.

Mason, S. J., \& Cole, M. H. (2002). Improving electronics manufacturing supply chain agility through outsourcing. International Journal of Physical Distribution \& Logistics Management, 32(7), 610-620.

Moradlou, H., Reefke, H., Skipworth, H., \& Roscoe, S. (2021). Geopolitical disruptions and the manufacturing location decision in multinational company supply chains: A Delphi study on Brexit. International Journal of Operations \& Production Management, 41(2), 102-130. 
Nandi, S., Sarkis, J., Hervani, A. A., \& Helms, M. M. (2021). Redesigning supply chains using blockchainenabled circular economy and COVID-19 experiences. Sustainable Production and Consumption, 27, 1022.

Ren, J., Li, H., Zhang, M., \& Wu, C. (2021). Massive-scale graph mining for e-commerce cold chain analysis and optimisation. Future Generation Computer Systems, 125, 526-531.

Rio-Chanona, R. M., Mealy, P., Pichler, A., Lafond, F., \& Farmer, J. D. (2020). Supply and demand shocks in the COVID-19 pandemic: An industry and occupation perspective. Oxford Review of Economic Policy, $36(1), 94-137$.

Rondinelli, D., \& Berry, M. 2000. Multimodal transportation, logistics, and the environment: Managing interactions in a global economy. European Management Journal, 18(4), 398-410.

Rönkkö, P., Isopoussu, A., Majava, J., \& Kauppila, O. (2021). An ability to survive disruptions - Findings from three Finnish manufacturing companies'supply challenges during the COVID-19 pandemic. Managing Global Transitions, 19(2), 105-126.

Sayed, M., Hendry, L. C., \& Zorzini Bell, M. (2021). Sustainable procurement: Comparing in-house and outsourcing implementation modes. Production Planning \& Control, 32(2), 145-168.

Sayer, A. (1986). New developments of manufacturing - The just-in-time system. Capital \& Class, 10(3), 4372.

Shaled, K. S., Azeem, A., Ali, S. M., \& Moktabir, A. (2021). A supply chain disruption risk mitigation model to manage COVID-19 pandemic risk. Environmental Science and Pollution Research, (2021), 1-16.

Simchi-Levi, D., Schmidt, W., \& Wei, Y. (2014). From superstorms to factory fires - Managing unpredictable supply-chain disruptions. Harvard Business Review, January-February, 96-101.

Studley, M. (2021). Onshoring through automation; Perpetuating inequality. Frontiers in Robotics and AI, 8. doi: $10.3389 /$ frobt.2021.634297

Thissen, M., van Oort, F., McCann, P., Ortega-Argilés, R., \& Husby, T. (2020). The implications of Brexit for UK and EU regional competitiveness. Economic Geography, 96(5), 397-421.

Tukamuhabwa, B. R., Stevenson, M., Busby, J., \& Zorzini, M. (2015). Supply chain resilience: Definition, review, and theoretical foundations for further study. International Journal of Production Research, 53, 5592-5623.

Yang, C-M., \& Chen, K-S. (2021). An integrated contract manufacturer selection and product quality optimisation methodology for the mechanical manufacturing industry. Expert Systems with Applications, 183, 115336.

Yang, H., Ou J., \& Chen, X. (2021). Impact of tariffs and production cost of a multinational firm's incentive for backshoring under competition. Omega, 105, 102500.

Yazdani, M., Mohammed, A., Bai, C., \& Labib, A. (2021). A novel hesitant fuzzy-based group decision approach for outsourcing risk. Expert Systems with Applications, 184, 115517.

Yin, R. K. (2003). Case Study Research: Design and Methods (3rd ed). California: Sage Publications, Inc.

Zanoletti, A., Cornelio, A., \& Bontempi, E. (2021). A post-pandemic sustainable scenario: What actions can be pursued to increase the raw materials availability? Environmental Research, 202, 111681. https://doi.org/10.1016/j.envres.2021.111681 